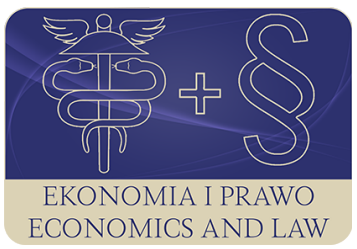

EKONOMIA I PRAWO. ECONOMICS AND LAW

Volume 16, Issue 4, December 2017

p-ISSN 1898-2255, e-ISSN 2392-1625

www.economicsandlaw.pl

ECONOMICS AND LAW

ORIGINAL ARTICLE

received 13.06.2017; revised 01.12.2017; accepted 31.12.2017

Citation: Gembalska-Kwiecień, A. (2017). Fundamentals of an effective corporate safety culture.

Ekonomia i Prawo. Ecomomics and Law, 16(4): 401-411. doi:10.12775/EiP.2017.028.

\title{
Fundamentals of an effective corporate safety culture
}

\author{
ANNA GEMBALSKA-KWIECIEŃ \\ Silesian University of Technology, Faculty of Organization and Management, Institute of Production \\ Engineering, ul. Roosevelta, 41-800 Zabrze, Poland \\ $\square$ anna.gembalska-kwiecien@polsl.pl
}

\begin{abstract}
Motivation: The paper presents basic issues related to a safety culture. It shows the explanation of terms 'culture' and 'organizational culture', which safety culture makes a part of. There is also presented a model of shaping of a safety culture. The empirical part presents the studies on the impact of an attitude and behaviour of employees on the development of safety culture based on the model of shaping of a safety culture.

Aim: The aim of the study was to analyze an attitude and behaviour of employees and their impact on shaping of a safety culture in a given enterprise. Research tools were: interview, documentation, analysis and anonymous survey given to enterprise employees.

Results: The study shows that majority of employees act in accordance with rules and try not to take risky actions, they also feel responsible for the safety of themselves and their co-workers; the environment and working conditions are in line with legal requirements, and accidents rarely occur.
\end{abstract}

Keywords: safety management; organization culture; safety culture; human factor; work environment

JEL: Il; D2; A3; L2

\section{Introduction}

The process of creation and implementation of safety management procedures requires, apart from technical actions, a significant attention given to the organization of profession selection, training schedule, improving professional skills, communication and motivation to safe conduct. However, these actions will not 
succeed, if they do not change the employees' attitude towards risk and do not teach them how to behave safely (Stoner et al., 2001; Studenski, 1996).

The paper presents the fundamental questions relating to the safety culture. It explains the terms such as 'culture' and 'organizational culture', which safety culture makes a part of. It contains also the information about the factors defining desired and undesired, good and bad safety culture and introduces a model of a safety culture development. The empirical part presents the study of an influence of employees' attitude and behavior on safety culture development, based on the model of safety culture development. The model elements studied are environment and conditions of work and employees' behavior and attitude. The research tools are: interview, analysis of the relevant documentation and anonymous survey carried out among employees of an enterprise.

The main goal of the study is to analyze employees' attitude and behavior together with their influence on safety culture development in an enterprise. The cognitive purpose that has been assumed is getting to know the employees' opinion regarding the work safety culture in the enterprise studied. The utilitarian purpose is to draw attention to the necessity of taking action to influence the employees attitude and behavior with regard to development of the work safety culture areas, with an aim to improve the safety in an enterprise.

\section{Literature review}

To get to know and understand the nature of safety culture we first need to get to know the idea of culture and organizational culture.

The study of enterprise's organizational culture, which commenced in the beginning of 80s, constitutes the foundation of the safety culture theory .

Changes happening worldwide impose on organizations the necessity to implement organizational culture. This culture should be flexible and sensitive to cultural differences, that members of an organization encounter within a given society and among various societies. Everybody has their own separate culture learned at home and society where they were brought up. When becoming a member of an organization they have to learn its culture, which can be realized by means of, among others, training and communication with the superiors and co-workers.

Belonging to an organizations entails being a part of its culture. The manner of working within a given organization has an enormous effect on its effectiveness. The basic assumptions accepted by the members of an organization and their interaction determine a part of an organizational culture (Gembalska-Kwiecień, 2005; Lewandowski, 2000; Stoner et al., 2001).

The very concept of organizational culture has originated by analogy with a national culture. The assumption that various nations and/or ethnic groups have various cultures has been accepted long time ago. Various organizations have various cultures as well, and the term organizational culture itself is defined in many ways. However, most often organizational culture is described 
as 'set of values, behavior patterns, specific communication forms and multiple other elements which consolidate the community spirit among the organization members' (Makin et al., 2000). The organizational culture can manifest itself in the dominating habits or habit patterns. Particularly it will manifest itself in the method of management (employees' assessment, building their career paths). Among the functions that it is performing there are: creation of the image within an organization, building of its goals awareness among the employees and inspiring their commitment to the goals accomplishment. The culture is formed by all the members of an organization and it manifests itself in behaviour, attitude, observed values and assumptions.

Most of the researchers who tackle the organizational culture perceive it as composed of a certain number of elements, existing at different levels of consciousness (Gembalska-Kwiecień, 2016; 2017).

Safety culture determines the attitude of people towards risk and safety. It formulates the rules of conduct and the values recognized by members of a given group.

When discussing safety culture we must bear in mind three main areas of management: people, information and organization. This is due to the fact that people are the subject of all managerial activities, because it is up to them whether safety management should be effective. Cooperation between employees and employers has a vital importance, because communication based on mutual trust is an essential feature of high safety culture. The employer is responsible for the safety and hygienic conditions of work and the life and health of his/her subordinates. However, the actions taken by the management will not suffice on their own, because this is mainly the employees, through their behaviour, sometimes risky and hazardous, who influence the safety level in workplace (Bugajska et al., 1998; Bird \& Germain, 1996).

Safety culture, however, refers not only to organizations but also a society, a group of people and individuals. Desired and undesired safety culture can be identified with regard to safety culture of an organization, a group of people, as well as individuals.

Each organization has got its own unique safety culture, therefore, organizations can be differentiated due to their safety culture. In this context we can differentiate between desired or undesired and good or bad safety culture.

To measure what degree is safety culture desirable or good we can tell by its ability to make decisions, generate attitudes and behavior, its organizational, technical, training and motivational achievements, which bring the organization closer to the absolute safety criterion.

After Pidgeon, the desired safety culture is characterized by (Podgórski \& Pawłowska, 2004; Studenski, 2000):

- high value given to life and health,

- no acceptance for hazardous behavior and risk-takers,

- disposition to eliminate any hazards,

- a need to clarify the reasons behind accidents that have happened. 
High safety culture is also related to each member's personal sense of responsibility for the safety issues, which is manifested in everyday life. Such behaviour should be formed and continuously strengthen as it does not always agree with 'the human nature' (Milczarek, 2000).

Most often mentioned features which characterize high safety culture are: safety treatment as a fundamental value, senior management commitment and leadership, employees commitment - participation and power transfer, the sense of personal responsibility of each employee for safety issues, free and open communication, OHS (Occupational Health and Safety) trainings adapted to the work specifics and employees' needs.

Additionally, the employees:

- reach out beyond their duties with regard to hazards and risky behaviour identification and taking the corrective actions,

- show a proactive stance and constant care for their own and others safety.

Low safety culture is characterized, among others, by showing no interest for safety issues among by the superiors, no need to comply with legal regulations and regarding them as useless, low standing of OHS issues in the value system of enterprise's community, supporting risky behavior, not using safety devices and personal protection equipment.

Low safety culture may as well originate from lack of sufficient knowledge with regard to safety and work organization demonstrated by both the employers and medium level supervisors, employers' insufficient economic motivation to ensure safe work conditions, lack of motivation among the employees to perform their tasks in a safe manner.

Safety culture should be continually developed to maintain its high level and to further improve it (Gembalska-Kwiecień, 2012).

Safety culture development must be a continuous process, because the actual culture shift is difficult and time-demanding. One-off actions to improve safety culture will bring only seeming effects, as they will reach only the most superficial culture stratum, termed 'artefact' by Schein (Podgórski \& Pawłowska, 2004; Studenski, 2000). To maintain a high level of safety culture we also need to reach deeper culture strata, i.e. the recognized values and fundamental assumptions.

During safety culture development three elements should be given special attention:

- the physical work environment (tools, machinery, workplace organization);

- employees' behaviour (complying with OHS regulations, information forwarding and cooperation, showing care for safety that reaches beyond standard duties);

- employees' intrinsic features (knowledge, skills, motivation).

The safety culture development model, shown in scheme 1, illustrates these three elements.

The above model shows that the effective development of high safety culture is influenced not only by work in an environment, but also by employ- 
ees' behaviour and their individual features. That is why, in order to achieve the desired level of safety culture it is necessary to ensure safe work conditions (machines and devices in working order, safe organization of workplace, etc.), to develop safe behaviour of employees (complying with OHS regulations, cooperation among employees and between employees and superiors, etc.) and to focus on employees' individual features (trainings, relevant motivation to behave safely, etc.)

Development of effective safety culture depends also on:

- an open and honest communication related to advising the employees about hazards and risks;

- management commitment, expressing personal concern and care for employees safety, complying with OHS regulations and handling the safety issues on equal terms with production issues;

- employees participation, for example participation in developing of inhouse standards and documentation related to OHS, in activities and decision-making in enterprise;

- OHS education, corresponding to the job performed and employees' needs;

- accident analysis, reporting and analysing of incident and potential incidents that occurred in the workplace, identification of causes and taking preventive measures;

- motivation and support awarded to safe behaviour, expressing the approval and recognition for employees who act safely and who engage in actions aiming at improvement of safety in the workplace;

- cooperation among the employees and the atmosphere of understanding and trust between the management and employees and between employees of various departments and organizational levels.

Additional factors that are conducive for development of safety culture:

- reinforcing the sense of community and developing work-related sense of pride among the employees;

- enabling the professional development and fulfilment of their own occupational ambition within enterprise;

- stress management through, among others, stress level assessment and monitoring among the employees, work satisfaction and pro-health prophylactic;

- promoting safe behaviour outside the workplace (on the way home, at home, during leisure).

All these actions help to develop safety culture on a high level, however, these cannot be one-off events, otherwise their effect will be short-lived. Safety culture requires constant perfecting.

Developing safety culture requires constant studies of this culture, which will allow to evaluate its level. Thanks to such studies, it is possible to determine what elements of culture require improvement, what steps should be taken to reach its high level (Milczarek, 2000; Podgórski \& Pawłowska, 2004; Studenski, 2000). 


\section{Methods}

The object of the study described in this paper is an enterprise from heating industry. However, it was not agreed to reveal its name, in order to enable employees to give reliable answers, as it was distinctly stressed during the briefing before the study proceeded. The enterprise's mission is to meet the demands of dwellers and industry in the above mentioned area with regard to uninterrupted delivery of water and continuous collection of sewage.

The study includes an analysis of the influence of employees' attitude and behavior on work safety culture in the enterprise studied. The object of the study were 240 randomly selected persons, holding different positions; 213 surveys were suitable for further processing.

The analysis of the influence of employees' attitude and behavior on work safety culture in the enterprise was carried out on the principle of safety culture development model, which comprises elements such as: work physical environment, employees' individual features and behavior.

To obtain the necessary information the following study methods were used:

- survey,

- interview,

- analysis of documentation.

The analysis of the employees' attitude and behavior was carried out on the basis of the survey which consisted of 21 closed questions. The employees had to choose one from the answers listed.

The analysis of the above data for accident types and causes in years 20122016 shows that:

1. 12 accidents happened in the enterprise in the years 2012-2016;

2. 2 women and 10 men were subject to accidents;

3. the average period of work in this enterprise among the injured was 7 years and 2 months;

4. with respect to their results all the accidents were classified as minor accidents;

5. the total of 'incapacity for work' days related to the accidents at work in the studied period amounted to 232 days. The most frequent injuries caused by accidents at work were sprain and dislocation of joints of upper and lower limbs, thigh injury and eyes injury;

6. the most frequent causes of accident were:

- incorrect organization of workplace;

- ignorance about hazards;

- insufficient concentration on the performed action;

- surprise at unexpected event;

- wrong work speed;

- lack of supervision;

- organizational shortcomings; 
7. the average number of accidents in the studied period of time amounted to just over 2.4 accidents per year. This fact proves that the accident rate in the enterprise is very low. Since all the accidents are classified as minor, it can be stated that work safety in the enterprise presents good level.

\section{Results}

Realization of the purpose of paper required a literature and documentation analysis in the surveyed enterprise, as well as interviews and anonymous survey among employees. The influence of attitude and behavior of employees for the development of safety culture in the enterprise was tested with a model-based development of safety culture, including such elements as: the physical environment of work and behaviors, attitudes and individual characteristics of employees. As a result of the research it can be stated that the safety culture in the enterprise affects not only the working environment, but also the attitude and behavior of its employees.

The study was conducted in three areas:

1. conditions and working environment:

- analysis of reports of environmental studies conducted in the enterprise has showed that the harmful factors do not exceed a specified standard. Working conditions comply with the requirements;

- interview conducted with the OHS inspector and documentation analysis shows that the working environment and OHS conditions are consistent with the standards and are constantly improving, and risks at workplaces, as far as possible, are successively eliminated. The enterprise cares about its employees and the natural environment;

2. accident rate:

- in years 2012-2016 there were 12 accidents at work;

- all these accidents were classified as a group of minor accidents, considering the effects of accidents;

- the average number of accidents during considered period was 2.4 accidents per year. Relating this to the number of employees (360 people), we can conclude that accidents at work per year is less than $0.7 \%$ of the workforce. This fact indicates that the accident rate in the enterprise is very low. Adding that all accidents belong to a group of minor accidents, it can be said that the work stations safety is at good level;

3. Attitude and behavior of employees:

- $52 \%$ of respondents say that they are motivated to safety work through posters, leaflets and talks, which may indicate that the researched enterprise properly performs the function of motivating employees to work safely;

- $53 \%$ of respondents pay attention to employees who do not respect OHS regulations, while $21 \%$ of employees report this problem to their supervisors, this indicates that employees understand the importance of matters relating to safety work and hazards, since $46 \%$ of respondents said that employees 
at the enterprise are involved in hazard identification and risk assessment at their work stations;

- $72 \%$ of the respondents believe that all employees have an influence on creating safe working conditions in the enterprise, 19\% say that superiors, $15 \%$ responded that an employee of the OHS department creates safe working conditions and $6 \%$ believes that it is the top management. According to the survey, more than half of employees believe that all employees in the workplace have an impact on creating a safe workplace, but the rest of the workers leave responsibility for creating safe working conditions, making them responsible, supervisors, OHS staff and top management;

- $82 \%$ of respondents treated OHS regulations as rules protecting against accidents, $8 \%$ treats them as impractical and unnecessary, while for $10 \%$ the OHS rules are difficulty in working. The above results show that in the enterprise a large majority of employees treat the regulations properly;

- $58 \%$ of respondents feel responsible for the safety of their co-workers, $29 \%$ have no opinion on the subject, while $9 \%$ did not feel responsible for the safety of co-workers. More than half of the respondents feel responsible for the safety of their colleagues, the others for various reasons have no opinion on this matter, or do not feel that responsibility;

- $87 \%$ of employees are aware of the hazards of their work station, $10 \%$ have no opinion about it, and 6\% do not know it. The results show that the awareness of hazards at the work stations among employees is very large, it raises the level of security in the enterprise, however, it is important to check that all employees know the hazards that may exist in their work stations;

- $42 \%$ of employees do not take risky actions during work, whereas 59\% of employees refuse to do the work when the place of work does not meet OHS requirements;

- $46 \%$ of surveyed employees believe that the most common cause of accidents at work is abusive behavior;

- for $44 \%$ of respondents OHS' trainings are necessary to be able to work safely, 38\% believe that providing trainings in the OHS area is needed, but trainings should be conducted in a more interesting form of classes. 52\% of respondents said that all the incident occurred in the enterprise are discussed at the courses, $22 \%$ of the respondents said that the consequences of accidents at work, and $14 \%$ that the suggestions and comments of employees regarding the improvement of OHS. This shows that accident taking place at the enterprise are discussed comprehensively, and also employees may make suggestions and comments to improve the level of safety.

\section{Conclusion}

Assumptions of the diagnosis of indirect safety culture indicate that if working conditions are in line with requirements, accidents are rare, and employees occasionally exceed OHS regulations, then such a state is a desirable safety culture. 
Studies have shown that most employees follow the rules and try not to take risky actions, and also they feel responsible for the safety of themselves and their co-workers, the environment and working conditions comply with legal requirements, and accidents happen rarely.

In the surveyed enterprise safety culture is high, as evidenced by, among other features: a sense of personal responsibility of each employee for safety matters, lack of acceptance for risk-takers, compliance with OHS regulations and appreciation of their validity, which are most frequently mentioned features that characterize high safety culture in the workplaces.

All enterprise's employees have impact on safety culture in the enterprise. The development of safe working conditions, including proper organization of work and the material and social work environment is a challenge facing the modern employer, but also, like the statistics on the causes of accidents at work show, also from the worker who in this process, on the one hand, is the subject of the employer's activities, but he is also a part influencing in an active way through their attitude and behavior to shape of working conditions.

\section{References}

Bird, F.E., \& Germain, G.L. (1996). Damage Control. A New Horizon in Accident Prevention and Cost Improvement. New York: American Management Association.

Bugajska, J., Konarska, M., Kurkus-Rozowska, B., \& Łuczak, A. (1998). Psychofizjologiczne problemy człowieka w środowisku pracy. Warszawa: CIOP.

Gembalska-Kwiecień, A. (2005). Czynnik ludzki w powodowaniu błędów podczas pracy. Praca Zdrowie Bezpieczeństwo, 1.

Gembalska-Kwiecień, A. (2012). Kształtowanie kultury bezpieczeństwa w przedsiębiorstwie. Zeszyty Naukowe Politechniki Śląskiej. Organizacja i Zarządzanie, 63a.

Gembalska-Kwiecień, A. (2016). Innovative forms supporting safe methods of work in safety engineering for the development of intelligent specializations. Management Systems in Production Engineering, 24(4). doi:10.12914/ MSPE-09-04-2016.

Gembalska-Kwiecien, A. (2017). Development of an Innovative Methodology Supporting Project Risk Management in the Manufacturing Enterprise of the Automotive Industry. Proceedings of the 6thInternational ConferenceonOperations Research and Enterprise Systems, 1. doi:10.5220/0006121102650271.

Lewandowski, J. (2000). Zarządzanie bezpieczeństwem pracy w przedsiębiorstwie. Łódź: Wydawnictwo Politechniki Łódzkiej.

Makin, P., Cooper, C.L., \& Cox, Ch.J. (2000). Organizacja a kontrakt psychologiczny. Warszawa: PWN.

Milczarek, M. (2000). Kultura bezpieczeństwa w przedsiębiorstwie - nowe spojrzenie na zagadnienia bezpieczeństwa pracy. Bezpieczeństwo Pracy nauka i praktyka, 10. 
Podgórski, D., \& Pawłowska, Z. (2004). Podstawy systemowego zarządzania bezpieczeństwem i higiena pracy. Warszawa: CIOP-PIB.

Stoner, A.F., Freeman, R.E., \& Gilbert, D.R. (2001). Kierowanie. Warszawa: PWE.

Studenski, R. (1996). Organizacja bezpiecznej pracy w przedsiębiorstwie. Gliwice: Wydawnictwo Politechniki Śląskiej.

Studenski, R. (2000). Kierowanie firmą bez wypadków i chorób zawodowych. Tarnobrzeg: Tarbonus.

\section{Acknowledgements}

Author contributions: author has given an approval to the final version of the article.

Funding: this research was undertaken as part of the Methods and tools for improving products and services on the selected examples (13/030/BK_17/0027) project and was fully funded by the Silesian University of Technology, Faculty of Organization and Management, Institute of Production Engineering. 


\section{Appendix}

Scheme 1.

Safety culture development

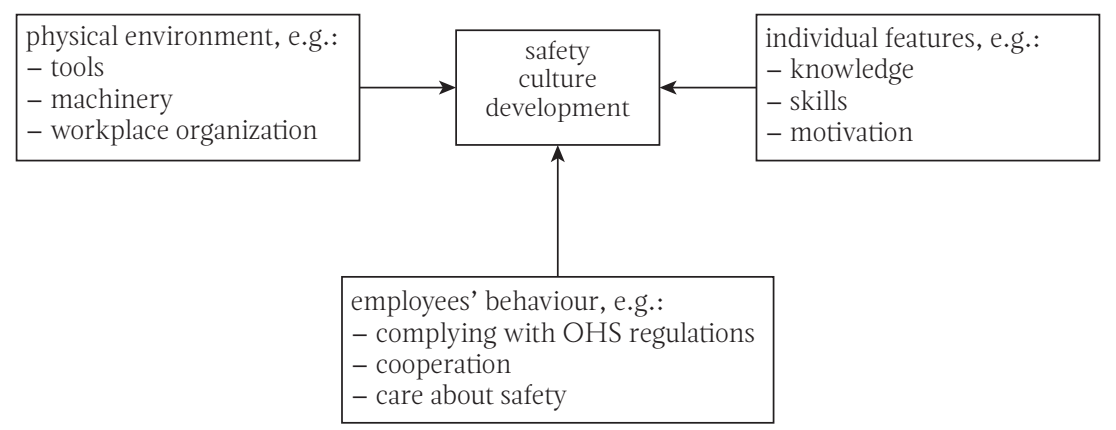

Source: Own preparation based on Podgórski \& Pawłowska (2004). 
